\title{
Lipofection of siRNA into bovine 8-16-cell stage embryos using zona removal and the well-of-the-well culture system
}

\author{
Shuntaro IKEDA ${ }^{1)}$, Miki SUGIMOTO ${ }^{1)}$ and Shinichi KUME ${ }^{1)}$ \\ 1) Laboratory of Animal Physiology and Functional Anatomy, Graduate School of Agriculture, Kyoto University, \\ Kyoto 606-8502, Japan
}

\begin{abstract}
Bovine preimplantation embryos exhibit dramatic biological changes between before and after the 8-16-cell stage. Here we report a simple lipofection method to transfect siRNA into bovine 8-16-cell stage embryos using zona removal and the well-of-the-well (WOW) culture system. Bovine one-cell embryos produced in vitro were freed from the zona pellucida and cultured up to the 8-16-cell stage in WOW dishes. The 8-16-cell embryos were lipofected with siRNA and the transfection efficiency was assessed at $48 \mathrm{~h}$ of transfection. Lipofection with a red fluorescent non-targeting siRNA revealed the importance of zona removal for transfection of siRNA into embryos. Using this method, we knocked down the methionine adenosyltransferase 2A $(M A T 2 A)$ gene, achieving a significant reduction in $M A T 2 A$ expression $(\mathrm{P}<0.05)$ concomitant with the marked inhibition of blastocyst development. Our proposed method, tentatively named 'Octo-lipofection', may be useful to analyze gene functions in bovine preimplantation embryos without expensive equipment and skill-intensive techniques.
\end{abstract}

Key words: Bovine, 8-16-cell, Lipofection, Preimplantation, siRNA

(J. Reprod. Dev. 64: 199-202, 2018)

$\mathbf{R}_{\text {i }}$ esearch aiming to elucidate the functions of specific genes in bovine preimplantation embryos routinely conducts RNA interference (RNAi) experiments involving the microinjection of siRNA into one-cell stage embryos. However, this method requires expensive micromanipulators and skill-intensive microinjection techniques. Furthermore, the microinjection generally must be performed at the one-cell stage [1-3]. Bovine preimplantation embryos exhibit dramatic biological changes between before and after the 8-16-cell stage, including changes in nutritional requirements [4], gene expression with major embryonic genome activation [5], and cellular lineage differentiation [6]. Accordingly, if we can begin RNAi from the 8-16-cell stage, it may be useful to analyze gene functions more precisely in bovine preimplantation embryos. Here we report a simple lipofection method to transfect siRNA into bovine 8-16-cell stage embryos using zona removal and the well-of-the-well (WOW) culture system $[7,8]$.

Zona-free one-cell embryos were prepared in WOW dishes and allowed to develop to the 8-16-cell stage (Fig. 1). At the 8-16-cell stage, embryos were lipofected with a red fluorescent non-targeting siRNA and the transfection efficiency was assessed at $48 \mathrm{~h}$ after the commencement of the lipofection (morula stage, Fig. 2). As a result, zona-free embryos exhibited significant red fluorescence, but zona-intact embryos did not. Thus, zona removal is important to introduce siRNA into embryos by lipofection. Importantly, zona

Received: October 13, 2017

Accepted: December 25, 2017

Published online in J-STAGE: January 21, 2018

(C)2018 by the Society for Reproduction and Development

Correspondence: S Ikeda (e-mail: ikedash@kais.kyoto-u.ac.jp)

This is an open-access article distributed under the terms of the Creative Commons Attribution Non-Commercial No Derivatives (by-nc-nd) License. (CC-BY-NC-ND 4.0: https://creativecommons.org/licenses/by-nc-nd/4.0/) removal (zona-removed $=62.9 \%$; not removed $=59.3 \%$; $\mathrm{SEM}=4.6$; $\mathrm{P}=0.6$ ) and lipofection (lipofected $=64.1 \%$; not lipofected $=58.1 \%$; $\mathrm{SEM}=4.6 ; \mathrm{P}=0.4$ ) did not affect the subsequent development to the blastocyst stage, and there was no significant interaction between these two factors $(\mathrm{P}=0.8)$. The harmlessness of the zona-removal to blastocyst yield in the WOW system is consistent with the results of the original report [7].

Next, we attempted to knockdown a specific gene using our proposed method. The methionine adenosyltransferase 2A (MAT2A) gene was selected because our previous findings suggested the importance of MAT2A in bovine preimplantation development, especially from the 8-16-cell stage up to the blastocyst stage, using a chemical inhibitor of MAT2A [9]. Lipofection of the MAT2A siRNA into the zona-free 8-16-cell embryos resulted in $35 \%$ and $88 \%$ reduction in $M A T 2 A$ mRNA expression relative to those of the control group at 24 and $48 \mathrm{~h}$ after the lipofection, respectively $(\mathrm{P}<$ 0.05 , Fig. $3 \mathrm{~A}$ ). Under this condition, development to the morula stage was not affected by the gene knockdown (data not shown). However, blastocyst development was almost $0 \%$ in the MAT2A-knockdown group, whereas $49 \%$ of the 8 -16-cell embryos on average developed to the blastocyst stage $(\mathrm{P}<0.0001$, Fig. $3 \mathrm{~B}$ and $\mathrm{C})$.

Taken together, the present method was successfully used for siRNA transfection into bovine 8-16-cell stage embryos with high knockdown efficiency. Our proposed method could help us to analyze the functions of specific genes in bovine preimplantation embryos without expensive equipment and skill-intensive techniques. The method was tentatively named 'Octo-lipofection' after the Latin prefix "octo-" meaning "eight-". As a note, lipofection of siRNA into bovine one-cell stage embryos using zona removal and a WOW system has already been published elsewhere [10]. In addition, the uses of WOW systems for embryo culture in non-bovine species have also been reported $[8,11]$. Therefore, the present method may 

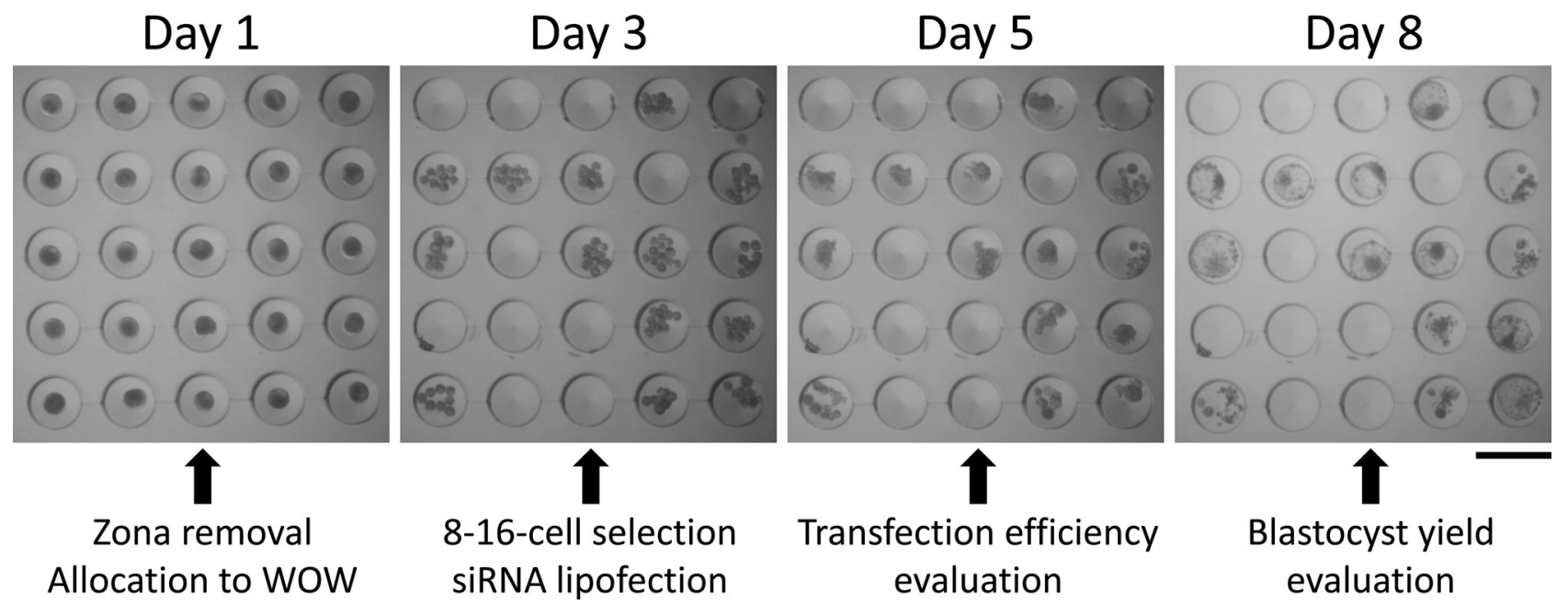

Fig. 1. The well-of-the-well culture and experimental scheme used in the present study. Bar represents $400 \mu \mathrm{m}$.
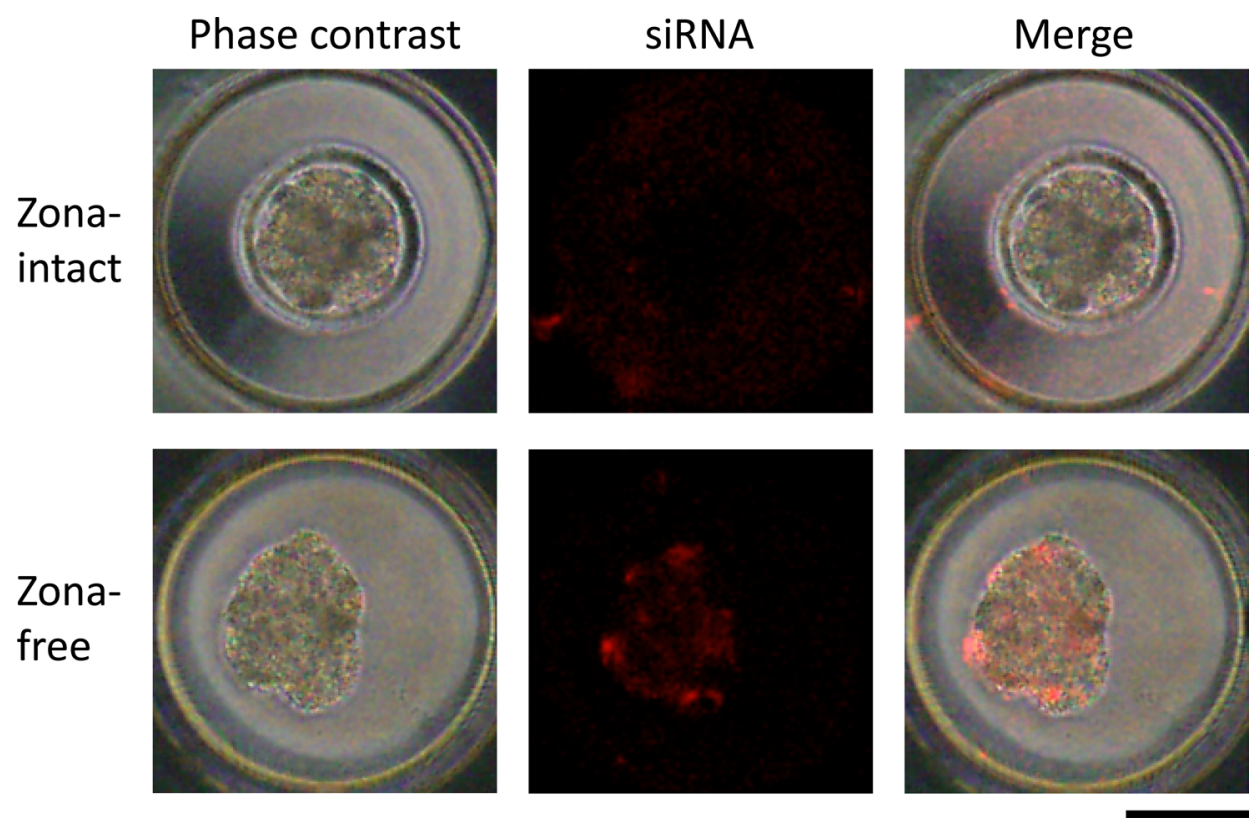

Fig. 2. Representative images of zona-intact and zona-free embryos that had been lipofected with the red fluorescent non-targeting siRNA. Bar represents $100 \mu \mathrm{m}$.

also be applicable for gene knockdown studies in other species.

\section{Methods}

siRNA lipofection into bovine 8-16-cell stage embryos

Bovine one-cell embryos were produced in vitro as previously described elsewhere [9]. At $20 \mathrm{~h}$ post-insemination (hpi), the embryos were treated with pronase solution $(0.5 \%[\mathrm{w} / \mathrm{v}]$ in $\mathrm{PBS}[+]$ containing $5.56 \mathrm{mM}$ glucose and $0.5 \mathrm{mM}$ sodium pyruvate) to remove the zona pellucida. The zona-free one-cell embryos were individually allocated to a WOW system [7, 8] using the LinKID micro25 culture dish (Dai Nippon Printing, Tokyo, Japan) with $50 \mu 1$ of modified synthetic oviduct fluid (mSOF) [12] and cultured until 72 hpi (day 3 ). At 72 hpi, only the embryos that had developed to the 8-16-cell stage were retained. siRNA lipofectant was prepared using the mSOF and Lipofectamine RNAiMAX reagent (Thermo Fisher Scientific, Waltham, MA) according to the manufacturer's instructions with some modifications, resulting in a lipofectant that was composed of mSOF containing $50-125 \mathrm{nM}$ siRNA and $0.3 \%(\mathrm{v} / \mathrm{v})$ of Lipofectamine RNAiMAX reagent. The 8-16-cell stage embryos were transfected 


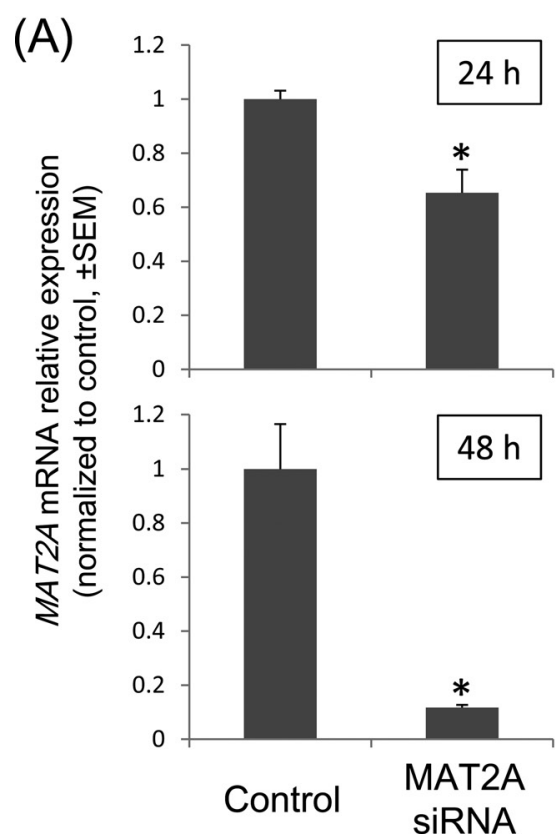

(B)

Control

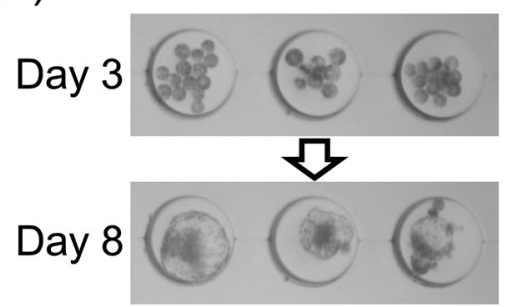

(C)

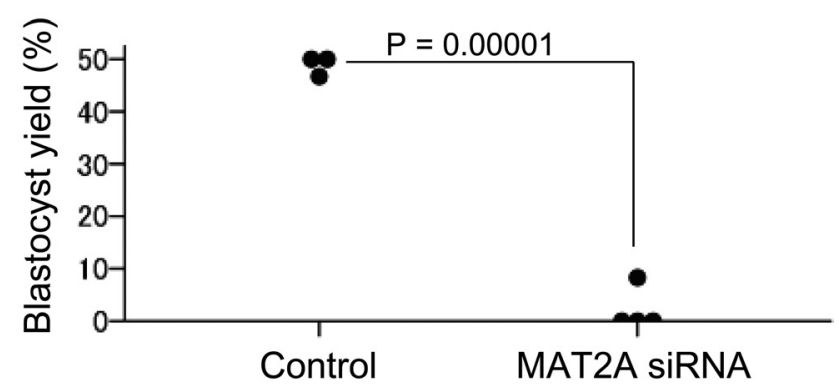

Fig. 3. (A) siRNA-based knockdown of $M A T 2 A$ in bovine in vitro-produced embryos. The expression of MAT2A was measured at 24 and $48 \mathrm{~h}$ after the siRNA transfection (days 4 and 5 of in vitro culture). Asterisks indicate significant differences from the control $(\mathrm{P}<0.05)$. (B) Representative images of the control and MAT2A-knockdown embryos on days 3 and 8 of in vitro culture. Bar represents $280 \mu \mathrm{m}$. (C) Blastocyst yield from the 8-16-cell stage in the control and MAT2A-knockdown groups on day 8. Each dot represents the blastocyst yield (\%) in each replicate.

with siRNA by replacing the culture medium with $50 \mu 1$ of the lipofectant and further cultured up to $192 \mathrm{hpi}$. All the cultures were performed at $38.5^{\circ} \mathrm{C}$ under $5 \% \mathrm{CO}_{2}, 5 \% \mathrm{O}_{2}$ and $90 \% \mathrm{~N}_{2}$.

Experiment 1: Assessment of transfection efficiency using red fluorescent non-targeting siRNA

To visualize the incorporation of siRNA into embryonic cells, we transfected a red fluorescent non-targeting siRNA (50 nM, BLOCKiT ${ }^{\text {TM }}$ Alexa Fluor ${ }^{\circledR}$ Red Fluorescent Control; Thermo Fisher Scientific) into bovine 8-16-cell stage embryos. At $48 \mathrm{~h}$ after the commencement of the transfection, the embryos were observed under a fluorescence microscope (FSX100; Olympus, Tokyo, Japan). We compared the transfection efficiency between zona-free and zona-intact embryos. In addition, the effects of zona removal and lipofection on development to the blastocyst stage were examined at 192 hpi (day $8 ; \mathrm{n} \approx$ 13/replicate, two-factorial design of "zona-removed or not" and "lipofected or not", 3 replicates).

\section{Experiment 2: Knockdown of MAT2A by siRNA lipofection}

To verify the knockdown efficiency against a specific gene using the proposed method, zona-free 8-16-cell stage embryos were lipofected with siRNA targeting the bovine $M A T 2 A$ gene as described above. The oligonucleotide sequences of the MAT2A siRNA were sense, 5'-CCAUUGUCUUAGCACACAATT-3'; and antisense, 5'-UUGUGUGCUAAGACAAUGGTT-3'. The sequences of the control siRNA were sense, 5'-GCAUACUACACACUUGUUUTT-3'; and antisense, 5'-AAACAAGUGUGUAGUAUGCTT-3', which had 90\% similarity in nucleotide composition with the target sequence and were designed not to target any bovine genes. The final concentration of siRNA added into the media was $125 \mathrm{nM}$. Gene knockdown efficiency was evaluated at $24(\approx 16$-cell stage) and $48 \mathrm{~h}$ (morula stage) after the transfection by oligo-dT-based reverse transcription-quantitative polymerase chain reaction (RT-qPCR) using RPS18 as an internal control ( $\mathrm{n} \approx 10$ and 7/replicate for 24 and $48 \mathrm{~h}$, respectively, 3 replicates). The primer pairs were 5'-AGACATTGGTGCAGGAGACC-3' and 5'-GCGTAACCAAGGCAAAGTGC-3' for $M A T 2 A$ and as in a previous report [1] for RPS18. The MAT2A primers were designed so that the primer pair bracketed the target sequence of the siRNA. In addition, development to the blastocyst stage was evaluated at 192 hpi ( $\mathrm{n} \approx 14 /$ replicate, 3 to 4 replicates).

\section{Statistical analysis}

In Experiment 1, embryonic development was analyzed using a general linear model to evaluate the effects of zona-removal and lipofection and their interaction, and the data were expressed as least squares means. In Experiment 2, data on embryonic development and the RT-qPCR were analyzed using the $t$-test. Significance was accepted at $\mathrm{P}<0.05$.

\section{Acknowledgements}

This work was supported in part by JSPS KAKENHI Grant Number 15K07779. 


\section{References}

1. Datta TK, Rajput SK, Wee G, Lee K, Folger JK, Smith GW. Requirement of the transcription factor USF 1 in bovine oocyte and early embryonic development. Reproduction 2015; 149: 203-212. [Medline] [CrossRef]

2. Takahashi K, Sakurai N, Emura N, Hashizume T, Sawai K. Effects of downregulating GLIS1 transcript on preimplantation development and gene expression of bovine embryos. J Reprod Dev 2015; 61: 369-374. [Medline] [CrossRef]

3. Yamanaka K, Sakatani M, Kubota K, Balboula AZ, Sawai K, Takahashi M. Effects of downregulating DNA methyltransferase 1 transcript by RNA interference on DNA methylation status of the satellite I region and in vitro development of bovine somatic cell nuclear transfer embryos. J Reprod Dev 2011; 57: 393-402. [Medline] [CrossRef]

4. Feugang JM, Camargo-Rodriguez O, Memili E. Culture systems for bovine embryos. Livest Sci 2009; 121: 141-149. [CrossRef]

5. Graf A, Krebs S, Heininen-Brown M, Zakhartchenko V, Blum H, Wolf E. Genome activation in bovine embryos: review of the literature and new insights from RNA sequencing experiments. Anim Reprod Sci 2014; 149: 46-58. [Medline] [CrossRef]

6. Wei Q, Zhong L, Zhang S, Mu H, Xiang J, Yue L, Dai Y, Han J. Bovine lineage specification revealed by single-cell gene expression analysis from zygote to blastocyst.
Biol Reprod 2017; 97: 5-17. [Medline] [CrossRef]

7. Vajta G, Peura TT, Holm P, Páldi A, Greve T, Trounson AO, Callesen H. New method for culture of zona-included or zona-free embryos: the Well of the Well (WOW) system. Mol Reprod Dev 2000; 55: 256-264. [Medline] [CrossRef]

8. Vajta G, Korösi T, Du Y, Nakata K, Ieda S, Kuwayama M, Nagy ZP. The Well-ofthe-Well system: an efficient approach to improve embryo development. Reprod Biomed Online 2008; 17: 73-81. [Medline] [CrossRef]

9. Ikeda S, Kawahara-Miki R, Iwata H, Sugimoto M, Kume S. Role of methionine adenosyltransferase $2 \mathrm{~A}$ in bovine preimplantation development and its associated genomic regions. Sci Rep 2017; 7: 3800. [Medline] [CrossRef]

10. O'Meara CM, Murray JD, Mamo S, Gallagher E, Roche J, Lonergan P. Gene silencing in bovine zygotes: siRNA transfection versus microinjection. Reprod Fertil Dev 2011 23: 534-543. [Medline] [CrossRef]

11. Dai SJ, Xu CL, Wang J, Sun YP, Chian RC. Effect of culture medium volume and embryo density on early mouse embryonic development: tracking the development of the individual embryo. J Assist Reprod Genet 2012; 29: 617-623. [Medline] [CrossRef]

12. Ikeda S, Sugimoto M, Kume S. The RPMI-1640 vitamin mixture promotes bovine blastocyst development in vitro and downregulates gene expression of TXNIP with epigenetic modification of associated histones. J Dev Orig Health Dis 2018; 9: 87-94. [Medline] [CrossRef] 